\title{
STOCHASTIC MODEL OF OPTIMAL DYNAMIC MEASUREMENTS
}

\section{A.A. Zamyshlyaeva ${ }^{1}$, A.V. Keller ${ }^{1}$, M.B. Syropiatov ${ }^{1}$}

${ }^{1}$ South Ural State University, Chelyabinsk, Russian Federation

E-mail: zamyshliaevaaa@susu.ru, kellerav@susu.ru, syr94@mail.ru

Under consideration is the stochastic model of optimal dynamic measurements. To solve this problem, the theory of optimal dynamic measurements which has actively been developing for the deterministic problems is extended to the stochastic case. The main purpose of the model is to restore a dynamically distorted input signal from a given observation using methods of the theory of dynamic measurements and the optimal control theory for Leontief type systems. Based on the results obtained by the authors earlier it is shown that optimal dynamic measurement as a minimum point of the cost functional doesn't depend on stochastic interference such as resonances in chains and random interference at the output of measuring transducer.

Keywords: stochastic problem; optimal dynamic measurement; cost functional.

\section{Introduction}

The stochastic problem of dynamic measurements can be considered within the framework of the general control theory, based, on one hand, on the deterministic description in the class of differential equations of the system itself, on the other hand on the stochastic description of the control and perturbing effects applied to it. One of the main characteristics of the control system is the dynamic accuracy of signal transmission or conversion, which is determined either by the difference or functional of the difference between the required and the actual values of the signal in time. There is a resonant problem, to get rid of noise in the observed signal, and to receive the measured signal in the required form. Since it is not possible to get rid of noise in full (in practice) even with the use of modern measuring instruments, filters and technical methods, there arises a question about mathematical solution of the problem, in particular with the use of methods of optimal control theory.

Mathematical model of measuring transducer (MT) is represented by the Leontief type system of equations (descriptor system [1])

$$
\left\{\begin{array}{c}
L \dot{x}=A x+B u \\
y=C x
\end{array}\right.
$$

where $L$ and $A$ are matrices that characterize the structure of the MT, in some cases it is possible that $\operatorname{det} L=0[2], x(t)$ and $\dot{x}(t)$ are vector functions of the state of the MT and the velocity of the state change, respectively; $y(t)$ is a vector-function of observations; $C$ is a rectangular matrix characterizing the interrelation between the system state and observation; $u(t)$ is a vector-function of measurements; $B$ is the matrix characterizing interrelation between the system state and measurement. If $L$ is not degenerate then system (1) can be reduced to

$$
\left\{\begin{array}{c}
\dot{x}=M x+F u \\
y=C x
\end{array}\right.
$$

where $M=L^{-1} A, F=L^{-1} B$. 
This system appeared in the dynamic measurements theory [3] from the remote control theory, where (2) was obtained in the study of the transfer function of the MT. Finally, in accordance to new approaches in the field of measurements [4], it is possible to replace the terms "input signal" to "measurement" and "output signal" to "observation", respectively. We emphasize that all observations and measurements in systems (1) and (2) are simulated or "virtual".

The initial Showalter - Sidorov condition

$$
\left[(\alpha L-A)^{-1} L\right]^{p+1}\left(x(0)-x_{0}\right)=0
$$

for some $x_{0} \in \mathbb{R}^{n}, \alpha \in \rho^{L}(M)$, reflects initial state of the MT. The initial Showalter Sidorov condition is equivalent to the initial Cauchy condition $x(0)=x_{0}$ in case $\operatorname{det} L \neq 0$.

The main goal of the theory of optimal dynamic measurements [5] is the restoration of a dynamically distorted input signal (measurement) $u(t)$ according to a given observation $y_{0}(t)$. When using this approach the key concept is the optimal dynamic measurement $v(t)$, which is constructed as a minimum of the functional

$$
J(v)=\min _{u \in U_{\partial}} J(x(u), u)
$$

on a set of admissible measurements $U_{\partial}$, where the pair $(x(u), u)$ satisfies system (1), and $U_{\partial}$ contains a priori information about measurements. The functional $J(x(u), u)$ reflects the evaluation of the proximity of actual observation $y_{0}(t)$ and virtual observation $y(t)$, obtained from (1). At present, within the framework of the theory of optimal dynamic measurements, the deterministic case is well studied [5,6] algorithms for solving such problems are constructed [7]. However, the deterministic problem does not take into account the effects of random interferences, which are always present in real processes, so it was suggested to use the stochastic model of MT

$$
\begin{gathered}
\left\{\begin{array}{c}
L \stackrel{o}{\xi}=A \xi+B(u+\varphi), \\
\eta=C \xi+\nu,
\end{array}\right. \\
{\left[(\alpha L-A)^{-1} L\right]^{p+1}\left(\xi(0)-\xi_{0}\right)=0 .}
\end{gathered}
$$

Here matrices $L, A, B, C$ have the same sense as in (1). Random processes $\varphi$ and $\nu$ determine noises in the circuits and at the output of the the MT respectively.

\section{Stochastic Leontief Type System in Spaces of "Noises"}

Let $\Omega \equiv(\Omega, \mathrm{A}, P)$ be a complete probability space, $\mathbb{R}$ be a set of real numbers, endowed with the Boreal $\sigma$-algebra. The measurable mapping $\xi: \Omega \rightarrow \mathbb{R}$ is called a random variable. The set of random variables with $E \xi=0$ and finite variance forms a Hilbert space $\mathbf{L}_{\mathbf{2}}$ with an inner product $\left\langle\xi_{1}, \xi_{2}>=E\left(\xi_{1} \xi_{2}\right)\right.$. Let $I \subset \mathbb{R}$ be some interval. The mapping $\eta: I \times \Omega \rightarrow \mathbb{R}$ of the form $\eta=\eta(t, \omega)$ is called a (one-dimensional) stochastic process, thus for every fixed $t \in I$ the value of the mapping $\eta=\eta(t, \cdot)$ is a random variable, i.e. $\eta=\eta(t, \cdot) \in \mathbf{L}_{2}$ and for every fixed $\omega \in \Omega$ the value of a stochastic process $\eta=$ $\eta(\cdot, \omega)$ is called the (sample) trajectory. The random process $\eta$ is called continuous, if almost surely all its trajectories are continuous. Denote by $C \mathbf{L}_{2}$ the space of continuous 
random processes. Continuous random process, which independent random variables are Gaussian, is called Gaussian. By $\stackrel{\circ}{\eta}^{(\ell)}$ denote the $\ell$-th Nelson - Gliklikh derivative of of the stochastic process $\eta[8]$. The set of continuous stochastic processes having continuous Nelson - Gliklikh derivatives up to order $k \in \mathbb{N}$ at each point of the set $I$ forms a space, which is denoted by $C^{k} \mathbf{L}_{2}$.

Consider the stochastic Leontief type system

$$
L \stackrel{\circ}{\xi}=A \xi+B(u+\varphi) .
$$

Where $u: I \rightarrow \mathbb{R}^{n}$ is a vector-function, $\varphi$ is a stochastic process. Let the matrix $A$ be $(L, p)$-regular, $p \in\{0\} \cup \mathbb{N}$, and initial states of (6) are described by the Showalter Sidorov condition

$$
\left[(\alpha L-A)^{-1} L\right]^{p+1}\left(\xi(0)-\xi_{0}\right)=0,
$$

where $\xi_{0}=\sum_{k=0}^{n} \xi_{0, k} e_{k}, \xi_{0, k}$ are the pairwise independent Gaussian random variables and $\left\{e_{k}\right\}_{k=1}^{n}$ is an orthonormal basis in $\mathbb{R}^{n}$.

Theorem 1. For any vector-function $u \in C^{p+1}\left(I, \mathbb{R}^{n}\right)$, initial values $\xi_{0}$ and stochastic process $\varphi \in C^{p+1} \mathbf{L}_{2}\left(I, \mathbb{R}^{n}\right)$ independent for every $t \in I$, there exists a unique solution $\xi$ of (6), (7) given by

$$
\xi(t)=\xi_{u}(t)+\xi_{\varphi}(t), \xi_{u} \in C^{1}\left(I, \mathbb{R}^{n}\right), \quad \xi_{\varphi} \in C^{1} \mathbf{L}_{2}\left(I, \mathbb{R}^{n}\right)
$$

where

$$
\xi_{u}(t)=\int_{0}^{t} U^{t-s} L_{1}^{-1} Q u(s) d s+\sum_{q=0}^{p}\left(M^{-1}\left(I_{n}-Q\right) L\right)^{q} M^{-1}\left(Q-I_{n}\right) u^{(q)}(t)
$$

is the deterministic part and

$$
\xi_{\varphi}(t)=U^{t} \xi_{0}+\int_{0}^{t} U^{t-s} L_{1}^{-1} Q \varphi(s) d s+\sum_{q=0}^{p}\left(M^{-1}\left(I_{n}-Q\right) L\right)^{q} M^{-1}\left(Q-I_{n}\right) \stackrel{\circ}{\varphi}(q)(t)
$$

is the stochastic part of the solution.

$$
\text { Here } U^{t}=\lim _{r \rightarrow \infty}\left(\left(L-\frac{t}{r} M\right)^{-1} L\right)^{r}, Q=\lim _{r \rightarrow \infty}\left(r L_{r}^{L}(M)\right)^{p}, L_{r}^{L}(M)=L\left(L-\frac{1}{r} M\right)^{-1},
$$

and $I_{n}$ is an identity matrix of order $n$.

Proof. Problem (6), (7) can be split into a deterministic

$$
\begin{gathered}
L \dot{\xi}_{u}=A \xi_{u}+B u \\
{\left[(\alpha L-A)^{-1} L\right]^{p+1}\left(\xi_{u}(0)\right)=0}
\end{gathered}
$$

and stochastic problems

$$
\begin{gathered}
L \stackrel{\circ}{\xi}_{\varphi}=A \xi_{\varphi}+B \varphi \\
{\left[(\alpha L-A)^{-1} L\right]^{p+1}\left(\xi_{\varphi}(0)-\xi_{0}\right)=0 .}
\end{gathered}
$$

Due to $(L, p)$-regularity of matrix $A$ there exists a unique solution [9] given by (9) of (11), (12). Using results on solvability of stochastic Sobolev type equations in spaces of "noises" [10-12] we can conclude existence of unique solution of stochastic Leontief type system (13), (14) as a particular case. 


\section{Stochastic Model of Optimal Dynamic Measurements}

The key concept is the optimal dynamic measurement simulated by solving the optimal control problem for (4), (5). For finding it introduce the space of measurements $U=\left\{u \in L_{2}\left(I, \mathbb{R}^{n}\right): u^{(p+1)} \in L_{2}\left((0, \tau), \mathbb{R}^{n}\right)\right\}$ and allocate in it a closed convex set of admissible measurements $U_{\partial} \subset U$ which contains a priori information about measurements Analogously to the deterministic case when investigating the problem of restoration a dynamically distorted signal by random interference in the circuits and at the output of MT, we consider the control problem

$$
J(v)=\min _{u \in U_{\partial}} J(u)
$$

where the cost functional

$$
J(u)=J(\eta(u))=\sum_{k=0}^{1} \int_{0}^{\tau} E\left\|\eta^{(k)}(t)-\eta_{0}^{(k)}(t)\right\|^{2} d t
$$

reflects the closeness of the real observation $\eta_{0}(t)$ and the virtual observation $\eta(t)$, obtained on the basis of mathematical model of the MT.

The minimum point $v(t)$ of the functional (16) on the set $U_{\partial}$, being a solution of optimal control problem (15) is called an optimal dynamic measurement. In practice, there is only indirect information about $v(t)$.

Theorem 2. Optimal dynamic measurement doesn't depend on random initial condition, noises in the circuits and at the output of the MT.

Proof. Since the input signal is a subject to noise in circuits and and at the output of MT, the virtual observation $\eta(t)$ is a stochastic process, the real observation $\eta_{0}(t)$ also varies from experiment to experiment and it can also be considered as a stochastic process with a finite expectation $\bar{\eta}_{0}(t)$ at each point $t \in I$. Denote by $\tilde{\eta}_{0}(t)$ a stochastic process $\eta_{0}(t)-\bar{\eta}_{0}(t)$ with zero expectation. Transform the cost functional

$$
\begin{aligned}
& J(u)=\sum_{k=0}^{1} \int_{0}^{\tau} E\left\|\eta^{(k)}(t)-\eta_{0}^{(k)}(t)\right\|^{2} d t= \\
& =\sum_{k=0}^{1} \int_{0}^{\tau} E\left\|C \stackrel{o}{\xi}^{(k)}(t)+\stackrel{o}{\nu}(k)-\left(\bar{\eta}_{0}(t)^{(k)}+\stackrel{\mathrm{o}}{\eta}_{0}^{(k)}(t)\right)\right\|^{2} d t= \\
& =\sum_{k=0}^{1} \int_{0}^{\tau} E\left\|C \xi_{u}^{(k)}(t)+C \stackrel{\mathrm{o}}{\xi}_{\varphi}^{(k)}(t)+\stackrel{\mathrm{o}}{\nu}^{(k)}-\left(\bar{\eta}_{0}^{(k)}(t)+\stackrel{\tilde{\eta}}{0}_{0}^{(k)}(t)\right)\right\|^{2} d t= \\
& =\sum_{k=0}^{1} \int_{0}^{\tau}\left\|C \xi_{u}^{(k)}(t)-\bar{\eta}_{0}^{(k)}(t)\right\|^{2} d t+ \\
& +2 \sum_{k=0}^{1} \int_{0}^{\tau} E\left(C \xi_{u}^{(k)}(t)-\bar{\eta}_{0}^{(k)}(t), C \stackrel{\mathrm{o}}{\xi}_{\varphi}^{(k)}(t)+\stackrel{\mathrm{o}}{\nu}^{(k)}-\stackrel{\tilde{\eta}}{0}_{0}^{(k)}(t)\right) d t+
\end{aligned}
$$




$$
\begin{gathered}
+\sum_{k=0}^{1} \int_{0}^{\tau} E\left\|C \stackrel{o}{\xi}_{\varphi}^{(k)}(t)+\stackrel{o}{\nu}(k)-\stackrel{\mathrm{o}}{\eta}_{0}^{(k)}(t)\right\|^{2} d t= \\
=\sum_{k=0}^{1} \int_{0}^{\tau}\left\|C \xi_{u}^{(k)}(t)-\bar{\eta}_{0}^{(k)}(t)\right\|^{2} d t+\sum_{k=0}^{1} \int_{0}^{\tau} E\left\|C \stackrel{\mathrm{o}}{\xi}_{\varphi}^{(k)}(t)+\stackrel{\mathrm{o}}{\nu}(k)-\stackrel{\mathrm{o}}{\eta}_{0}^{(k)}(t)\right\|^{2} d t .
\end{gathered}
$$

Thus, noises and random initial condition do not affect the optimal dynamic measurement as a minimum point of cost functional. They affect only the value of the optimality criterion, namely, it increases.

Remark 1. The theorem allows us to assert the possibility of applying numerical algorithms developed for the deterministic case [13] to solve the problem of restoration of the measured signal distorted by stochastic interference. In the future, it is planned to modify the methods of finding the optimal dynamic measurement in the presence of noise.

Acknowledgements. The work was supported by Act 211 Government of the Russian Federation, contract No. 02.A03.21.0011.

\section{References}

1. Belov A.A., Kurdyukov A.P. Descriptor Systems and Control Problems. Moscow, FIZMATLIT, 2015. (in Russian)

2. Khudyakov Yu.V. On Mathematical Modeling of the Measurement Transducers. Journal of Computational and Engineering Mathematics, 2016, vol. 3, no. 3, pp. 68-73. DOI: $10.14529 /$ jcem160308

3. Granovsky V.A. Dynamic Measurements: Theory and Metrological Assurance at Yesterday and Tomorrow. Sensors and Systems, 2016, no. 3, pp. 57-72. (in Russian)

4. Ruhm K.H. Dynamics and Stability - A Proposal for Related Terms in Metrology from a Mathematical Point of View. Measurement: Journal of the International Measurement Confederation, 2016, vol. 79, pp. 276-284. DOI: 10.1016/j.measurement.2015.07.026

5. Shestakov A.L., Keller A.V., Sviridyuk G.A. Optimal Measurements. XXI IMEKO World Congress "Measurement in Research and Industry", 2015, pp. 2072-2076.

6. Shestakov A.L., Sagadeeva M.A., Sviridyuk G.A. Reconstruction of a Dynamically Distorted Signal with Respect to the Measuring Transducer Degradation. Applied Mathematical Sciences, 2014, vol. 8, no. 41-44, pp. 2125-2130. DOI: 10.12988/ams.2014.312718

7. Keller A.V., Shestakov A.L., Sviridyuk G.A., Khudyakov Yu.V. The Numerical Algorithms for the Measurement of the Deterministic and Stochastic Signals. Springer Proceedings in Mathematics and Statistics, 2015, vol. 113, pp. 183-195. DOI: 10.1007/978-3-319-12145-1_11

8. Gliklikh Yu.E., Mashkov E.Yu. Stochastic Leontieff Type Equations and Mean Derivatives of Stochastic Processes. Bulletin of the South Ural State University. Series: Mathematical Modelling, Programming and Computer Software, 2013, vol. 6, no. 2, pp. 25-39.

9. Shestakov A.L., Sviridyuk G.A., Khudyakov Yu.V. Dynamical Measurements in the View of the Group Operators Theory. Springer Proceedings in Mathematics and Statistics, 2015, vol. 113, pp. 273-286. DOI: 10.1007/978-3-319-12145-1_17 
10. Zamyshlyaeva A.A., Sviridyuk G.A. The Linearized Benney - Luke Mathematical Model with Additive White Noise. Springer Proceedings in Mathematics and Statistics, 2015, vol. 113, pp. 327-337. DOI: 10.1007/978-3-319-12145-1_21

11. Zagrebina S.A., Soldatova E.A. Linear Sobolev Type Equations with Relatively $p$-Bounded Operators and Additive White Noise. News of Irkutsk State University. Series: Mathematics, 2013, vol. 6, no. 1, pp. 20-34. (in Russian)

12. Favini A., Sviridyuk G.A., Manakova N.A. Linear Sobolev Type Equations with Relatively p-Sectorial Operators in Space of "Noises". Abstract and Applied Analysis, 2015, vol. 2015, p. 697410 . DOI: $10.1155 / 2015 / 697410$

13. Khudyakov Yu.V. The Numerical Algorithm to Investigate Shestakov - Sviridyuk's Model of Measuring Device with Inertia and Resonances. Mathematical Notes of YSU, 2013, vol. 20, no. 2, pp. 211-221. (in Russian)

Received April 17, 2018

УДК 517.9

DOI: $10.14529 / \mathrm{mmp} 180212$

\title{
СТОХАСТИЧЕСКАЯ МОДЕЛЬ ОПТИМАЛЬНЫХ ДИНАМИЧЕСКИХ ИЗМЕРЕНИЙ
}

\author{
А.А. Замыиляева ${ }^{1}$, А.В. Келлер ${ }^{1}$, М.Б. Съропятов ${ }^{1}$ \\ ${ }^{1}$ Южно-Уральский государственный университет, г. Челябинск, \\ Российская Федерация
}

\begin{abstract}
Рассматривается стохастическая математическая модель оптимальных динамических измерений, которая позволяет осуществить восстановление динамически искаженного входного сигнала по заданному наблюдению с использованием методов теории динамических измерений и теории оптимального управления для систем леонтьевского типа. Для ее исследования теория оптимальных динамических измерений, которая активно развивалась для детерминированных задач, распространяется на стохастический случай. На основе результатов, полученных авторами ранее, показано, что оптимальное динамическое измерение как точка минимума функционала не зависит от стохастических помех, таких, как резонансы в цепях и случайные помехи на выходе измерительного устройства.

Ключевые слова: стохастическая модель; оптимальное динамическое измерение; функиионал качества.
\end{abstract}

Статъя выполнена при поддержке Правительства РФ (Постановление № 211 om 16.03.2013 г.), соглашение № 02.A03.21.0011.

\section{Литература}

1. Белов, А.А. Дескрипторные системы и задачи управления / А.А. Белов, А.П. Курдюков. - М.: ФИЗМАТЛИТ, 2015. - 300 с.

2. Khudyakov, Yu.V. On Mathematical Modeling of the Measurement Transducers Yu.V. Khudyakov // Journal of Computational and Engineering Mathematics. - 2016. V. 3, № 3. - P. 68-73. 
3. Грановский, В.А. Динамические измерения: теория и метрологическое обеспечение вчера и сегодня / В.А. Грановский // Датчики и системы. - 2016. - № 3. - С. 57-72.

4. Ruhm, K.H. Dynamics and Stability - A Proposal for Related Terms in Metrology from a Mathematical Point of View / K.H. Ruhm // Measurement: Journal of the International Measurement Confederation. - 2016. - V. 79. - P. 276-284.

5. Shestakov, A.L. Optimal Measurements / A.L. Shestakov, A.V. Keller, G.A. Sviridyuk // XXI IMEKO World Congress «Measurement in Research and Industry». - 2015. - P. 2072-2076.

6. Shestakov, A.L. Reconstruction of a Dynamically Distorted Signal with Respect to the Measuring Transducer Degradation / A.L. Shestakov, M.A. Sagadeeva, G.A. Sviridyuk // Applied Mathematical Sciences. - 2014. - V. 8, № 41-44. - P. 2125-2130.

7. Keller, A.V. The Numerical Algorithms for the Measurement of the Deterministic and Stochastic Signals / A.V. Keller, A.L. Shestakov, G.A. Sviridyuk, Yu.V. Khudyakov // Springer Proceedings in Mathematics and Statistics. - 2015. - V. 113. - P. 183-195.

8. Gliklikh, Yu.E. Stochastic Leontieff Type Equations and Mean Derivatives of Stochastic Processes / Yu.E. Gliklikh, E.Yu. Mashkov // Вестник ЮУрГУ. Серия: Математическое моделирование и программирование. - 2013. - Т. 6, № 2. - С. 25-39.

9. Shestakov, A.L. Dynamical Measurements in the View of the Group Operators Theory / A.L. Shestakov, G.A. Sviridyuk, Yu.V. Khudyakov // Springer Proceedings in Mathematics and Statistics. - 2015. - V. 113. - P. 273-286.

10. Zamyshlyaeva, A.A. The linearized Benney - Luke Mathematical Model with Additive White Noise / A.A. Zamyshlyaeva, G.A. Sviridyuk // Springer Proceedings in Mathematics and Statistics. - 2015. - V. 113. - P. 327-337.

11. Загребина, С.А. Линейные уравнения соболевского типа с относительно рограниченными операторами и аддитивным белым шумом / С.А. Загребина, Е.А. Солдатова // Известия Иркутского государственного университета. Серия: Математика. 2013. - T. 6, № 1. - C. 20-34.

12. Favini, A. Linear Sobolev Type Equations with Relatively p-Sectorial Operators in Space of "Noises" // A. Favini, G.A. Sviridyuk, N.A. Manakova // Abstract and Applied Analysis. 2015. - V. 2015. - P. 697410.

13. Худяков, Ю.В. Алгоритм численного исследования модели Шестакова - Свиридюка измерительного устройства с инерционностью и резонансами / Ю.В. Худяков // Математические заметки ЯГУ. - 2013. - Т. 20, № 2. - С. 211-221.

Алена Александровна Замышляева, доктор физико-математических наук, доцент, кафедра «Прикладная математика и программирование», ЮжноУральский государственный университет (г. Челябинск, Российская Федерация), zamyshliaevaaa@susu.ru.

Алевтина Викторовна Келлер, доктор физико-математических наук, доцент, кафедра «Математическое и компьютерное моделирование», Южно-Уральский государственный университет (г. Челябинск, Российская Федерация), kellerav@susu.ru.

Михаил Борисович Сыропятов, аспирант, кафедра «Прикладная математика и программирование», Южно-Уральский государственный университет (г. Челябинск, Российская Федерация), syr94@mail.ru.

Поступила в редакиию 17 апреля 2018 г. 